\title{
HELICOPTER-ASSISTED RADIOMETRIC
} SURVEY OF THE DIXON ENTRANCE QUADRANGLE, ALASKA

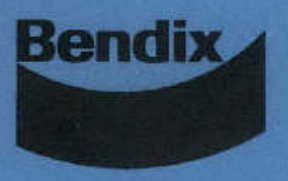

Field Engineering Corporation

Grand Junction Operations

February 1979

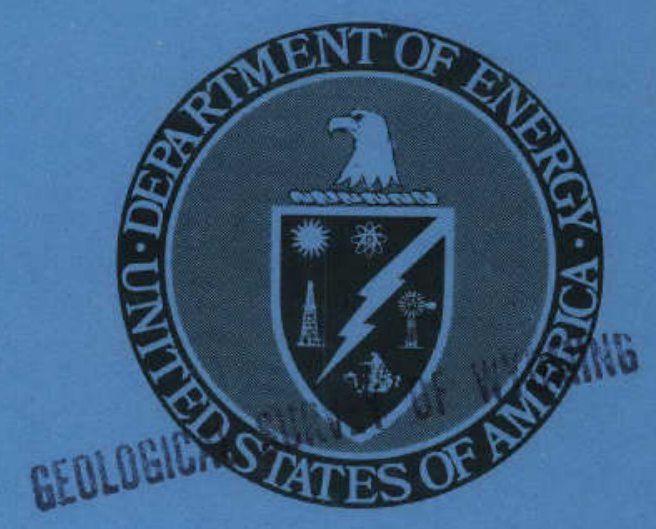

ISSUED BY THE U.S. DEPARTMENT OF ENERGY GRAND JUNCTION, COLORADO 81501 
This report was prepared as an account of work sponsored by the United States Government. Neither the United States nor the United States Department of Energy, nor any of their employees, nor any of their contractors, subcontractors, or their employees, makes any warranty, express or implied, or assumes any legal liability or responsibility for the accuracy, completeness, or usefulness of any information, apparatus, product, or process disclosed, or represents that its use would not infringe privately owned rights. 
GJBX-19(79)

\title{
HELICOPTER-ASSISTED RADIOMETRIC SURVEY OF THE DIXON ENTRANCE QUADRANGLE, ALASKA
}

W. A. Burgett and K. J. Krause

\author{
BENDIX FIELD ENGINEERING CORPORATION \\ Grand Junction Operations \\ Grand Junction, Colorado 81501
}

February 1979

PREPARED FOR THE U.S. DEPARTMENT OF ENERGY GRAND JUNCTION OFFICE

UNDER CONTRACT NO . EY-76-C-13-1664 

CONTENTS

$\underline{\text { Page }}$

Introduction . . . . . . . . . . . . . . . . . . . . . . 1

Rationale and objectives . . . . . . . . . . . . . . . . . . . 1

Previous work . . . . . . . . . . . . . . . . . . . 3

Procedures......................... . . . . . 3

Results . . . . . . . . . . . . . . . . . . . . . 4

Discussion of results . . . . . . . . . . . . . . . . . . . . . . 4

Conclusions . . . . . . . . . . . . . . . . . . . . . . . 5

Bibliography . . . . . . . . . . . . . . . . . . . 6 
Figure 1. Location map of Dixon Entrance Quadrangle . . . . . . . . 2

Plate 1. Dixon Entrance D-1 Quadrangle.............. in pocket 1a. Bokan Mountain area ................ in pocket 2. Dixon Entrance D-2 Quadrangle . . . . . . . . . In pocket 3. Dixon Entrance D-3 Quadrangle............ . in pocket 4. Dixon Entrance D-4 Quadrangle............. in pocket 5. Dixon Entrance C-1 Quadrangle.... . . . . . . . in pocket 6. Dixon Entrance $\mathrm{C}-3$ Quadrangle . . . . . . . . . . in pocket 7. Prince Rupert D-6 Quadrangle . . . . . . . . . in pocket 


\section{INTRODUCTION}

The Dixon Entrance Quadrangle (Fig. 1), in southeast Alaska, is currently belng investigated by Bendix Field Engineering Corporation (BFEC) as part of the National Uranium Resource Evaluation (NURE) program, under direction of the U.S. Department of Energy. The on1y reported uranium production in Alaska to date has come from the Bokan Mountain area, which is in the northeastern part of the quadrangle near the southern end of Prince of Wales Island.

The initfal phase of the investigation was a reconnaissance-level radiometric survey conducted by helicopter. This report presents the data retrieved, a description of the equipment and methods used, and comments based on preliminary interpretations of the results. The report is being open-filed to make available the data to those who may plan investigations in this region or who may consider using a similar radiometric surveying technique in comparable circumstances. A final report for the Dixon Entrance Quadrangle evaluation is scheduled early in 1980 .

\section{RATIONALE AND OBJECTIVES}

Review of available information indicated that, due to the nature of topography, vegetation, overburden, and access logistics, most of the Dixon Entrance Quadrangle would have to be evaluated by indirect methods. Most of the land area in the quadrangle is covered by rain forest, muskeg, or shallow ponds and lakes. Glacial debris masks bedrock in several areas, although it is neither thick nor extensive. Although the area has been surveyed radiometrically on a regional basis as part of the NURE Aerial Radiometric Reconnaissance Survey program, results had not been released at the time of this project. Detailed geologic information, as well as other geophysical information, is not available for most of the quadrangle.

Objectives of this survey were:

(1) to determine the radiometric expression of the Bokan Mountain granite and associated uraniferous rocks, so that comparable favorable environments might be recognized radiometrically;

(2) to delineate unreported areas or geologic units favorable for the possible occurrence of uranturn deposits;

(3) to help locate lithologic contacts and bedrock exposures mostly obscured by cover; and

(4) to gather information about logistics for use in planning future field investigations that must be done under tight budget and time constraints. 


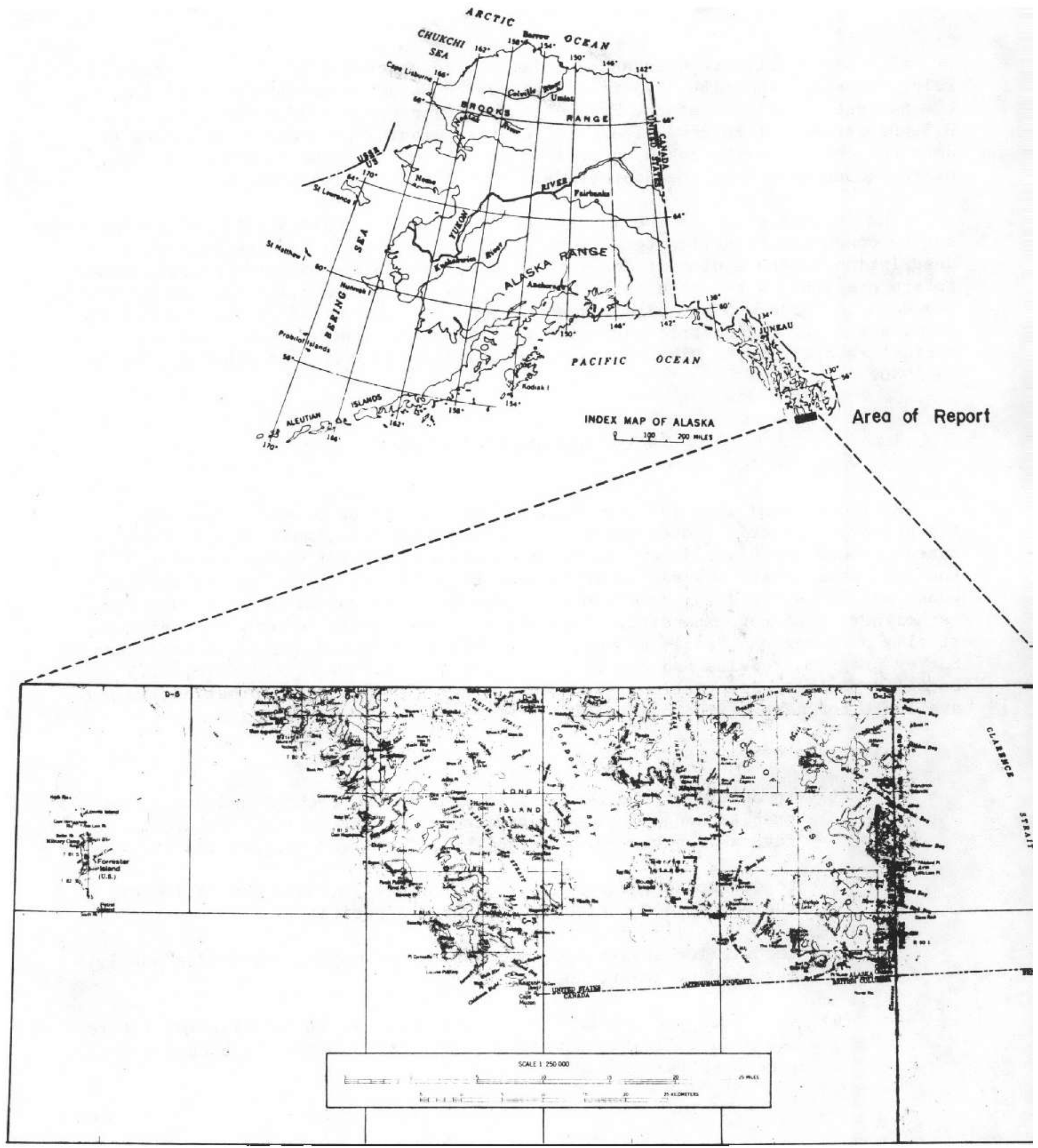

Figure I. Location map of Dixon Entrance Quadrangle. 
PREVIOUS WORK

Previous geologic work in the quadrangle includes reconnaissance shoreline mapping by Buddington and Chapin (1929) and detailed studies of the geology of the Bokan Mountain uraniun-thorlum area by MacKevett (1958, 1959, and 1963) and Eakins (1970). MacKevett's work includes a 1:24,000-scale geologic map that. covers approximately 20 percent of the land area in the quadrangle. Eberlein and Churkin (1970) studied the Paleozoic stratigraphy along the northwest coast of Prince of Wales Island, which is outside and north of the Dixon Entrance Quadrangle. Beikman (1975) included the maps from the above studies in a $1: 1,000,000-$ scale geologic-compilation map.

\section{PROCEDURES}

The project was conducted in May 1978 and required 30 hours of aircraft time to survey approximately 1,000 line miles. The equipment utilized in the survey consisted of (1) a four-channel gamma-ray spectrometer (Scintrex GAD-4), (2) a spectrum stabilizer (Scintrex RSS-3), (3) a gamma-ray detector (Scintrex GSA-64) composed of 452 cubic inches of NaI crysta1, and (4) a six-channel strip-chart recorder (Scintrex RC-6-DC). The system was mounted in a Hiller 12-E (turbine) helicopter. Flight altitude and speed of the aircraft were approximately $200 \mathrm{ft}$ (above terrain) and $60 \mathrm{mph}$, respectively.

The spectrometer was operated in the four-channel differential mode with a built-in stripping factor selected to correct for Compton scatter. The continuous output of the spectrometer was recorded on the strip-chart recorder in separate channels for uranium, thorium, potassium, and total (gross gamma) count. Before being operated in the survey, the system was checked on the Bendix calibration pads at Grand Junction, Colorado, and tt was carefully checked before and during daily survey flights.

Navigation was done visually and position was plotted manually on topographic maps. Preliminary flight lines were plotted on the maps prior to the survey, based on topography and geologic and geophysical information available for some parts of the quadrangle. The actual flight paths were superimposed on the maps during the survey, and location marks were added to the maps and the strip charts simultaneously so that the radionetric data recovered could be plotted later in thelr correct location on maps. Observations about rock type and the presence of water and vegetative cover, which might influence the radiometric signal, were also noted on the maps and charts.

Flight paths were selected principally to include as much outcrop as possible and were therefore mostly along ridgetops and along the coast at low tide. Secondary paths were flown parallel to topographic contours to include outcrop or rock-rubble areas. Areas obviously underlain by thick Quaternary deposits were largely ignored, but adequate coverage was obtained to assure that major geologic environments would be surveyed and that unsuspected large areas of possible strong radiometric response would not be missed. 
RESULTS

Flight paths and the equivalent uranium (eU) and thorium (eTh) values measured are presented in Plates 1 through 7, which consist of six 1:63,360-scale maps and one 1:15,840-scale map of parts of the Dixon Entrance Quadrangle, as we11 as one 1:63,360-scale map of part of the adjoining Prince Rupert Quadrangle. Spectrometer outputs from the uranium and thorium channels are given in counts per second (cps) on the plates, and the data have been grouped along the flight lines for legibility using a quasilogarithmic scale $(<10,10-20,20-50,50-100$, and $>100 \mathrm{cps})$. Those segments of the flight lines where the helicopter was too high to obtain acceptable data are so noted.

Many factors affect the propagation and measurement of terrestrial gamma radiation. These include water, vegetation, soil cover and moisture, the geometry of the crystal detector in relation to the gamma-ray source, and the natura1 radioelement concentrations in the source materials (Darnley, 1975). Because of such factors, evaluation of the data is largely subjective, and, for our purposes, an "anomaly" is defined as a pronounced increase in counts per second above the general background radioactivity for the entire flight line, the area surveyed, or, if known, the lithologic unit. It should be noted that Plates 1-7 depict the data only as counts per second and that "anomalous" cps do not necessarily signify anomalous concentrations of uranium or thorium.

Data recovered for radiometric potassium and total count have not been included in Plates $1-7$ but are preserved on the original strip charts, which are available for inspection at the BFEC field office in Anchorage. These data, together with those for uranium and thorium, will be used to determine areas of probable outcrop that were not readily visible during the survey because of dense tree cover, and to locate possible geologic contacts. Further interpretation of apparent anomalous radioactivity recorded in the survey will be made at a later date on the basis of information collected in scheduled field investigations.

\section{DISCUSSION OF RESULTS}

Comments that follow are based chiefly on preliminary interpretations of the radiometric $U$ and Th data shown on the plates and partly on minimal field checking of a few areas. The highest eU and eTh values on Plate 1 are due to the Bokan Mountain granite, which is clearly anomalous as compared to the surrounding sedimentary and other granitic rocks. Much lower values of eU and eTh (10 cps) shown to the immediate south of Bokan Mountain (secs. 27-29) correspond to a unit mapped as black slate (MacKevett, 1963). Farther south (secs. 32 and 33 ) eU and eTh values in the 10-50 cps range reflect bedrock mapped as quartz monzonite and granodiorite. The high values $(50 \mathrm{cps}$ eU and eTh) on line 15 between location marks 1 and 2 indicate the Ross-Adams uranium mine. These results show that grid surveying on l-mile spacing would clearly reveal a uraniferous environment comparable to that exposed at Bokan Mountain.

A few eU and eTh anomalies occur along flight lines south of McLean Arm (P1s. 1 and 7). On 1ines 6 and 7 (P1. 7) the 10-50 cps values probably are due to andesite dike swarms that intrude quartz monzonite. The 20-100 cps values along line 8 (P1. 7) and the 10-50 cps values along line 24 past location mark 24 (P1. I) were probably caused by andesite dike swarms that intrude syenite. 
The anomalous radioactivity indicated at the ends of flight lines 4 and 5 (P1. 4) is attributed to unexpected uranium content in an area mapped as limestone of Paleozoic age, which extends northward 1nto the Craig Quadrangle. Equivalent uranium increased to nine times background for this general area, whereas eTh remalned uniformly low. Soll samples (a blufsh-gray clay) contained as much as $300 \mathrm{ppm}$ (fluorometric) uranium, which indicates that this environment warrants a more detailed ground follow-up investigation.

Anomalous eU and eTh indicated in Plate 5 reflect chiefly granitic rock exposed along the coastline at low tide. Dike swarms observed between location marks 4 and 9 on line 1 did not cause any apparent anomalous response, as did similar swarms detected on flight paths shown on Plates 1 and 7 , probably because they generate a radiometric signal similar to the rocks that enclose them.

Many low-level "anomalies" observed are attributed to bedrock exposures that are inherently low in radioelements but which contrast radiometrically with surrounding masked areas. Such areas are thus anomalous solely because they are not covered by vegetation, wet soil, glacial debris, or other overburden. Separation of anomalies due to uranium and (or) thorium concentrations from "apparent" anomalies caused by other sources was not possible during this survey but will be a prime objective of fleld investlgations scheduled as part of the overall evaluation of the Dixon Entrance Quadrangle. For the time being, all indicated anomalles are consldered to be important, even as guides to possible areas of bedrock from which more detailed geologic knowledge of the area can be gained during field work.

\section{CONCLUSIONS}

Known uraniferous rocks at Bokan Mountain were well expressed radiometrically, and the type of survey conducted is capable of detecting similar geologic environments that might exist at the surface elsewhere in the quadrangle. No similar uraniferous environments were indicated, however.

Strong radionetric (eU) anomalies were detected in a limestone terrane in which uranium is not generally expected to occur in anomalous concentrations. These anomalies have hlgh priority in plans for future field work and occur in an environment that may have been overlooked in previous Investigations in the area.

A fringe benefit of conducting such a survey is the logistical information derived. Notes plotted on the maps and strip charts during flight regarding areas of outcrop and preliminary identification of lithologies are being used to plan follow-up field investigations required to fully evaluate the quadrangle. 


\section{BIBLIOGRAPHY}

Beikman, H. M., 1975, Preliminary geologic map of Southeast Alaska: U.S. Geological Survey Misc. field studies, Map MF-673, scale 1:1,000,000.

Buddington, A. F., and Chapin, T., 1929, Geology and mineral deposits of Southeastern Alaska: U.S. Geol. Survey Bu11. 800, 398 p.

Darnley, A. G., 1975, Geophysics in uranium exploration, in Uranium Exploration '75: Geol. Survey of Canada Paper 75-26, p. 21-31.

Eakins, G. R., 1979, An experiment in geobotanical prospecting for uranium in the Bokan Mountain area: Alaska Dept. of Natural Resources, Div. of Mines and Geology, Geol. Rept. 41, 52 p.

1975, Uranium investigations in Southeast Alaska: Div. of Geol. and Geophys. Surveys, College, Alaska, Geo1. Rept. 44, 62 p.

Eberlein, G. D., and Churkin, M., Jr., 1970, Paleozolc stratigraphy in the northwest coastal area of Prince of Wales Island, Southeastern Alaska: U. S. Geol. Survey Bull. 1284, 67 p.

MacKevett, E. M., Jr., 1958, Geology of the Ross-Adams uranium-thorium deposit, Alaska, in Peaceful uses of atomic energy: United States 2nd Internat. Conf., Geneva, Switzerland Proc., p. 502-508.

1959, Geology of the Ross-Adans uranium deposit, Alaska: Mining Eng., vol. 11, no. 9, p. 915-919.

1963, Geology and ore deposits of the Bokan Mountain uranium-thorium area, Southeastern Alaska: U.S. Geo1. Survey Bu11. 1156, 125 p. 


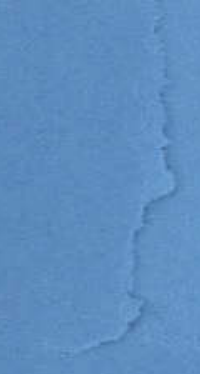

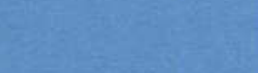
Stong

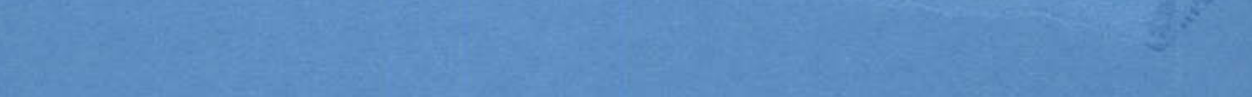

5.

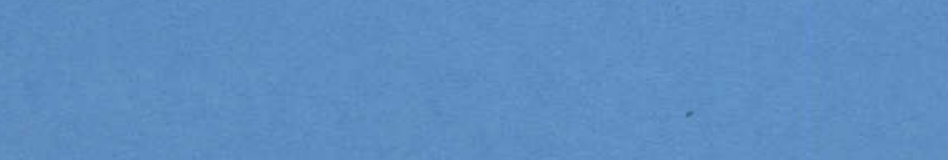

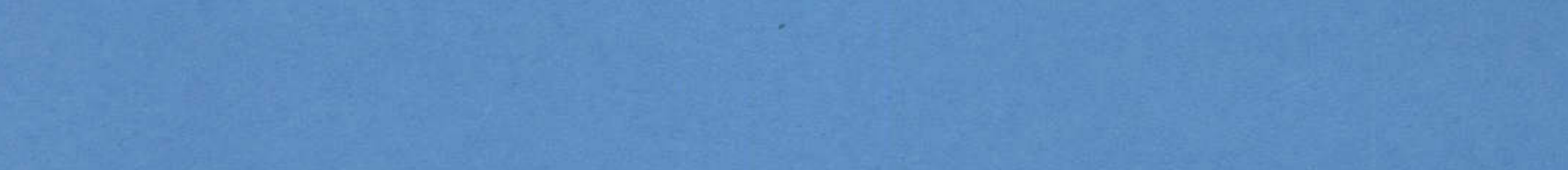

(2)

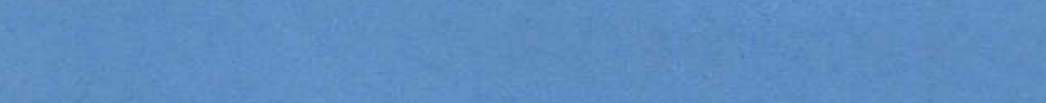

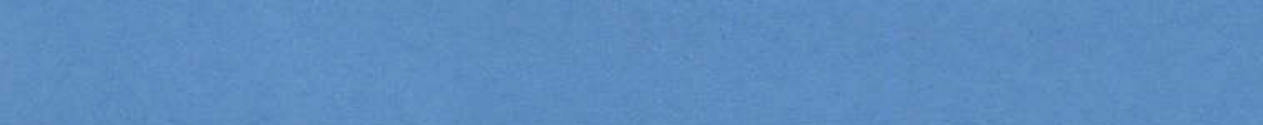

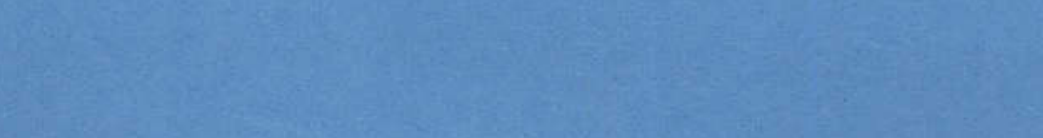

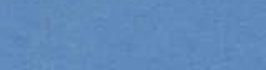

(2)

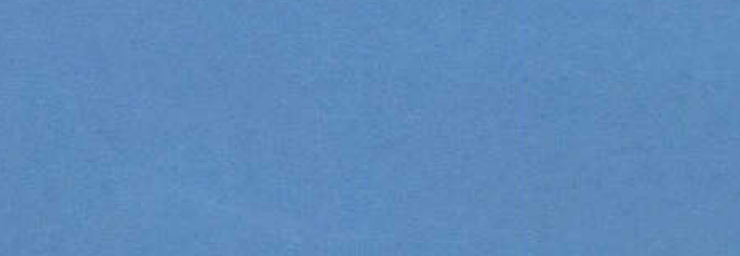

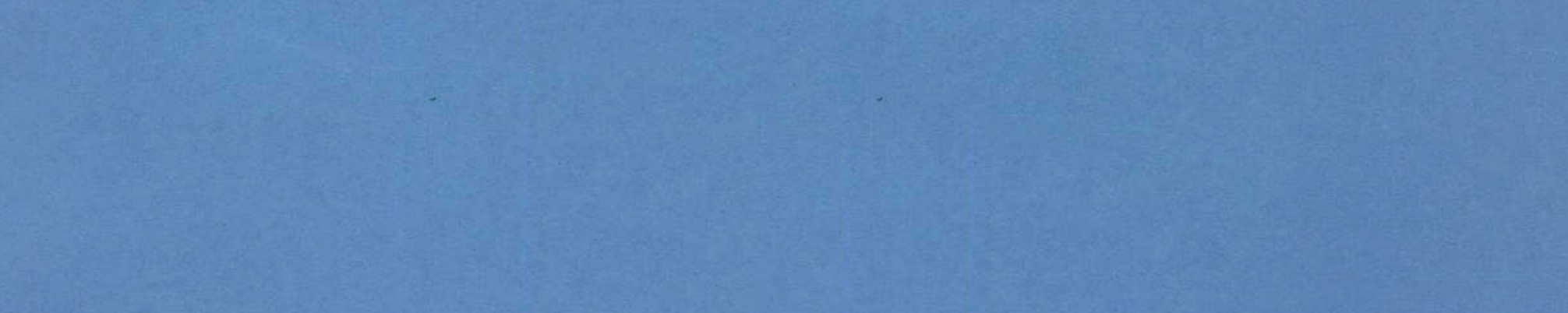

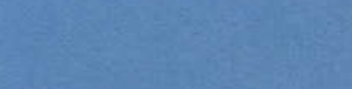

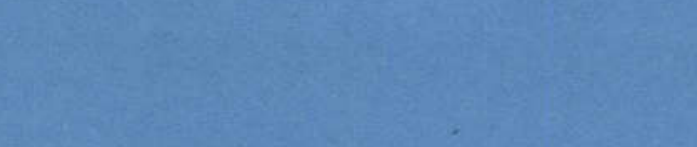

1. 1 a 
